RESEARCH ARTICLE

\title{
Holiday Brides and Policy Concerns: The Perils of Being in "NO- Man's" Land
}

\author{
Sonia Kapur* \\ Interdisciplinary Studies, UNC Asheville, US
}

\begin{abstract}
The term "holiday brides" became popular in India in the 1990s to refer to wives who were abandoned by their Non-resident Indian (NRI) husbands who returned back alone to their prosperous foreign lands, mainly US, UK and Canada, soon after marriage. The abandonment is apparent when months and years pass by, but the husband does not visit, contact or send any paper work for their spouse to join them in their foreign locations. Shame which prevents many women from reporting such incidents combined with the dearth of studies on the subject matter has resulted in only estimates being available of the number of "holiday brides" in India. Studies estimate that there are close to 30,000 such women in the state of Punjab alone in India. Through an examination of 21 key case laws adjudicated in the Indian courts and literature review, the paper examines the interplay of factors that lead to distinct challenges to advance the legal rights of "holiday brides," given their so-called transnational identity. An interplay of factors--breakdown of traditional social institutions, globalization, and policy perspectives--shape the unique nature of challenges experienced by this social group of women: women whose "womanhood" is interrupted by the creation of the holography. Through a more holistic approach involving societal and policy-based interventions, this paper highlights the need for a comprehensive international policy to advance justice for the holiday brides.
\end{abstract}

\section{Keywords}

Holiday brides, NRI, wives

Open Access

Citation: Kapur, S. Holiday Brides and Policy Concerns: The Perils of Being in "NO-Man's" Land. Gender and Women's Studies. 2019; 2(3):2.

Received: January 26, 2019

Accepted: June 21, 2019

Published: July 5, 2019

Copyright: @ 2019 Kapur S. This is an open access article distributed under the terms of the Creative Commons Attribution License, which permits unrestricted use, distribution, and reproduction in any medium, provided the original author and source are credited.

Corresponding author:

Sonia Kapur, Interdisciplinary Studies,

UNC Asheville, US

E-mail:skapur@unca.edu

\section{Introduction}

In 2018, a group of 8 abused women filed a public interest litigation in the Supreme Court of India seeking protection of the fundamental rights of women abandoned by their NRI husbands. While the case is still under consideration, it is interesting to note that in the last 3 years, close to 4300 complaints relating to NRI marriages in foreign countries have been reported which makes it important to draw the attention of the government to the cultural, social, and political factors for action (Venkatesan, 2018).

In India, it is considered a norm that a woman will leave her parental home to live with her husband and/or his family after marriage. In fact, almost two-thirds of all Indian women migrate for marriage (Fulford, 2015). Close to $90 \%$ of the women in India enter into matrimonial relationships through an arranged marriage set up (www.abcnews.com). In a majority of the cases they marry men who have been introduced to them through common relatives or friends, and most often the couple does not have enough time, opportunity, or consent of their parents and family to date prior to the marriage decision. This implies that only limited familiarity can develop between the couple prior to being married. The lack of familiarity is compounded if the person being considered for the matrimonial alliance lives and works in foreign lands. While we know that in comparison to men, a majority of women migrate to foreign lands to join their spouse, however, there are no estimates of the number of women who marry a spouse living/working in foreign lands and, therefore, leave or fail to leave for 
foreign lands to join him. In some cases, this kind of residential set-up is a ground for domestic violence since the woman is left to care for the husband's parents and other relatives back home. Therefore, domestic violence has been noted to occur in both situations: 1) where the wife goes to stay with the husband in foreign lands, is ignored and later abandoned and, also, 2) where the wife keeps waiting in the homeland for the husband to take responsibility and send the paperwork for her to join him in the foreign land. The common element of domestic violence across both the above described scenarios is what advocates term as "transnational abandonment."

To elaborate, often, when a woman moves with her husband to foreign lands after marriage, she, subsequently, may be deceptively sent back to the home country, and/or,on her vacation to India find herself being abandoned, while the husband leaves back for foreign lands. A significant number of women also land up in situations where they get married when the man comes to India on vacation and soon after the marriage, abandons the wife and returns back to the foreign lands. The confluence of transnational mobility in the context of traditional practices among the South Asian community creates specific challenges (Bhattacharjee, 2013; Stewart, 2013). While extant literature (Grewal \& Kaplan, 2002) has focused, though in a limited way, on the former situation and analyzed the flexibility of boundaries as they change and shift the political, cultural, and social aspects/ landscapes in a foreign land, very little attention has been paid to the cases of the second set of women which is explored in this paper. It is this set of women primarily classified as "holiday brides" who are the focus of this paper.

\section{Research Question and Methodology}

The term "holiday brides" became popular in India in the 1990s to refer to wives who were abandoned by their Non-Resident Indian (NRI) husbands who returned back to their prosperous foreign lands, mainly US, UK and Canada, soon after marriage and abandoned their wives. The abandonment is apparent when months and years pass by, but the husband does not contact or send any paper work for their spouse to join them in their foreign locations. In short, the husband negates all responsibility towards his wife. Another variation of this is when the husband does come back occasionally for some years and then abandons all contact one fine day leaving the wife with no recourse for future. Shame which prevents many women from reporting such relationships combined with the dearth of studies on the subject matter have resulted in only estimates being available of the number of "holiday brides" in India. The paper examines the interplay of factors that come into play and lead to distinct challenges to advance the legal rights of "holiday brides," given their so-called transnational identity.

This is an exploratory study to determine the factors that lead to the situation, dilemmas and injustices that holiday brides face in seeking justice. Consequently, two methods of data collection were used. First, I examined 21 landmark cases that have been adjudicated in the Indian courts related to the issue of abandoned wives. These cases are considered case laws on the subject matter by the National Commission for Women (NCW), a government organization at the national level for advancing the welfare and rights of women in India. The case laws gathered ranged from court judgements passed over a period of 4 decades, from the 1970's through 2000s. The themes that emerged from these case laws were coded to examine the research question of this study.

Second, to triangulate the first method of data collection, a review of literature was also undertaken to identify the factors that interplay and lead to a distinct situation, dilemmas and injustice for the women. Consequently, policy initiatives and existing literature was studied to untangle the different interrelated aspects for a deeper understanding of the issues and concerns. Secondary literature was gathered and studied on the theme through a search of key words and phrases. From the studies gathered, the themes that emerged were coded and sub-coded and clubbed with the themes from the case laws to arrive at the findings for the study.

Research indicates that an interplay of factors - breakdown/continuation of traditional social institutions; globalization; and policy perspectives---shape the unique nature of challenges experienced by this social group of women; women whose "womanhood" is interrupted by the creation of the holography. The interruption is largely on account of the maintenance of status quo since the women have very little legal recourse given the 
transnational character of such relationships and therefore by virtue of their issues falling in "no-man's land," holiday brides experience some distinct challenges in attaining justice. The interplay of factors has implications to address the phenomenon through a more holistic approach involving societal and policy-based interventions.

\section{Findings \& Discussion}

A study of case laws reveals that of the 21 key case laws highlighted by the National Commission for Women, 9 were adjudicated in 2000's, 5 each in 1980's and 1990's and 1 each in 1960's in 1970's. The relatively higher number of case laws in the 1990's and 2000's can primarily be attributed to the high incidence of women reporting about their situations and taking up the legal battle for their rights and subsequently the media attention. This implies that the higher number may not necessarily be indicative of higher occurrence, but, could only be a factor of higher reporting. Subsequently, as the cases were highlighted, more initiatives to address the issue were taken up. A key theme that runs across the court proceedings is determining which courts have jurisdiction over the matter; the Indian court or the foreign court. One key aspect of these initiatives that has been an integral aspect of a number of such cases of abandoned women is the restraint on the husband to continue with court proceedings in the foreign country. A key aspect that most court cases have dealt with is about the scope of jurisdiction. Even while recognizing the need for Indian courts to maintain jurisdiction in most of the cases, there has been somewhat of a variation in where the cases are adjudicated based on when and whether the wife can appeal to the courts in a timely manner before the decision of the courts abroad are made. Since women wait, do not have the legal or financial resources among other important things, they are at an inherent disadvantage as they are unlikely to receive a significant financial remedy through the foreign courts (Patel, Handa, Anitha and Jahangir (n.a.). Table 1 highlights the issues discussed in case laws over the course of 4 decades from 1970's-2000's.

Table 1. Issues discussed in the case laws over the course of 4 decades

\begin{tabular}{|c|c|c|c|}
\hline 2000's & 1990's & 1980's & 1970's \\
\hline $\begin{array}{l}\text { 1)Restraint order on } \\
\text { continuing divorce } \\
\text { proceedings in the US if } \\
\text { the spouse has not } \\
\text { consented for legal } \\
\text { proceedings there } \\
\text { 2)If order passed by US } \\
\text { court, decree will } \\
\text { unlikely receive } \\
\text { recognition in India, so } \\
\text { bigamy in India- } \\
\text { criminal offence } \\
\text { 3)Impound/revocation of } \\
\text { passport if he fails to } \\
\text { respond to summons of } \\
\text { Indian court } \\
\text { 4)Custody of children } \\
\text { issue should follow the } \\
\text { best interest of the child, } \\
\text { hence not illegal to bring } \\
\text { a foreign born child } \\
\text { back to India. } \\
\text { 5)Under Hindu Marriage } \\
\text { Act there cannot be no }\end{array}$ & $\begin{array}{l}\text { 1)The foreign court's } \\
\text { divorce decree was } \\
\text { rejected since the case } \\
\text { had already been filed } \\
\text { by the wife in India } \\
\text { 2)Courts have upheld } \\
\text { mental and emotional } \\
\text { cruelty and payment of } \\
\text { damages to the wife } \\
\text { accordingly } \\
\text { 3)Recommendations } \\
\text { have been made to make } \\
\text { provisions that no } \\
\text { marriage between NRI } \\
\text { and Indian women can } \\
\text { be annulled in foreign } \\
\text { land; provisions should } \\
\text { be made for alimony to } \\
\text { wife in property of } \\
\text { husband in India and } \\
\text { abroad; decree granted } \\
\text { by Indian court can be } \\
\text { executed in foreign } \\
\text { courts }\end{array}$ & $\begin{array}{l}\text { 1)Child custody in } \\
\text { line with the best } \\
\text { interest of the } \\
\text { child. } \\
\text { 2)Child custody in } \\
\text { line with principle } \\
\text { of comity. }\end{array}$ & $\begin{array}{l}\text { 1)Used the principle } \\
\text { of 'real and } \\
\text { substantial } \\
\text { connection' to } \\
\text { decide child custody } \\
\text { issue. } \\
\text { 2) Recognized the } \\
\text { right of a wife to } \\
\text { approach the court } \\
\text { on the basis of the } \\
\text { principle of 'real and } \\
\text { substantial } \\
\text { connection' to a } \\
\text { place, overruling } \\
\text { that of wife and } \\
\text { children following } \\
\text { husband/father's } \\
\text { domicile. }\end{array}$ \\
\hline
\end{tabular}




\begin{tabular}{|c|c|}
\hline $\begin{array}{l}\text { fault divorce in foreign } \\
\text { country, when woman } \\
\text { has not consented for the } \\
\text { same in the foreign court } \\
\text { 6)The question of which } \\
\text { court has jurisdiction } \\
\text { over the matter has been } \\
\text { widely debated by the } \\
\text { Indian courts across all } \\
\text { the cases. }\end{array}$ & $\begin{array}{l}\text { 4)Best interest of the } \\
\text { child in determining } \\
\text { place of residence } \\
\text { 5)The jurisdiction of } \\
\text { Indian court would be } \\
\text { there in matters where } \\
\text { the petitioner has been } \\
\text { living in India for } 3 \\
\text { years prior to the filing } \\
\text { of the petition and } \\
\text { therefore short-term } \\
\text { visits abroad do not } \\
\text { mean residence change, } \\
\text { hence the cases can be } \\
\text { filed in Indian court. }\end{array}$ \\
\hline
\end{tabular}

It is clear form Table 1 that there are several key issues that the Indian courts deal with while adjudicating on cases related to abandonment of women by their NRI spouses. In analyzing the case laws along with the existing literature in the field, the following factors are of critical importance in comprehensively understanding the situation of holiday brides.

\section{Changing or continuous forms of traditional social institutions}

Men of Indian descent are often brought up in a patriarchal culture that believes in the superiority of the man and subjugation of women. A multitude of factors come into play to determine why men come back to marry women in their home country in India (Kalita, 2005; Abraham, 2008). First, is the inability to find a "traditional" woman in the foreign land (Abraham, 2008). Traditional in this context largely means, someone who is subservient to the man and has an aspect of sacrificing her own happiness for maintaining the security, protection, and sanctity of her marriage even at grave costs to her. Second, men experience societal and family pressure to conform and adhere to values which are consistent with their Indianness - values which propagate the idea that women should take up family and caregiving responsibilities for both the children and elderly parents. Marriage in India is "between families" and often the groom's family is looking for a bride who would take on family responsibilities, bear children, and act as a care giver for the elderly parents. Furthermore, men feel pressured to marry within their own caste and community. Third, the financial status is both a pull factor for the bride's as well as the groom's family. Even though this may be far from the truth, the groom, since he works and earns in a foreign land is considered a prosperous and highly sought-after prospect for marriage. The implication of this is that the grooms' family is better placed to demand a huge dowry from the bride's family and the bride's family by paying a high dowry believes that they are ensuring their daughter's future and wellbeing (Biao, 2008). In fact, due to the globalization, the demand for dowry is higher than ever before (Bradley, Tomalin \& Subramaniam, 2009; Jehan, 2011; Waheed, 2009; Biao, 2008). Studies (Anitha, Roy \& Yalamarty, 2016) indicate the links between demand for dowry and the abandonment of women. As Nigam (2019) states "the common pattern that emerged across those real live stories is that the NRI men marry Indian women, demand huge dowry, sexually exploit them, then these men go abroad promising these young brides that they will arrange for the visas for the women, but many keep on waiting"(n.a.). Focus on consumerist culture places a high value on economic status and wealth to which the bride's family succumbs (Kumari, 2010). In the context of an arranged marriage, paying a high dowry to solicit such matches for their daughters, parents believe they can secure the future of their daughters who would be well-cared for in their matrimonial home (John, 2010). On the other hand, the rise of individualism and demise of moral bondages have complicated the system of transnational arranged marriages which in traditional contexts did create somewhat of a societal pressure to 
maintain marriage bonds at least in some instances but this is no longer the norm now.

\section{Globalization}

Interestingly, while the reasons for such transnational marriages may immediately place women in the subordinate position, all is not bleak. While men marry women in India for mainly all or some of the above stated reasons, India is no longer monolithic in the way cultures and traditions are perceived and experienced. With modernity, Indian women are getting more educated, moving out of the confines of the home to take up jobs and spaces in professional spheres (Liddle \& Joshi, 1986). The trends of globalization have not kept Indians isolated. The popular cinema of Bollywood also plays an important role in shaping gender identity and equality issues. Bollywood in its formative years depicted women as being the guardians of Indian culture and moral values (Prasad, 1998). Of course, recent trends in Bollywood have made a shift towards depicting women as empowered enough to question and challenge the moral values in favor of greater gender equality. In fact, the recent incidents of violence against women in India with the Nirbhaya case wherein a young woman was gang raped have sparked grassroots movements across the country for women's equal rights. Consistent with all of this, women are beginning to question their place and role in family spheres even though there is a long way ahead. However, as Dhawan (2005: 81) highlights there remains a complexity "between a woman's objective roles and her subjective attitudes regarding these roles."The objective implying the empowerment and subjective the dilemmas and contradictions that women face because of their own socialization and thereby use their own moral compass to conform to subordinate positions.

Similarly, in the context of the phenomenon of holiday brides, several women have come forward to demand restitution for their problems and stigma, while many others remain silent because of the dilemma they encounter between objective and subjective conceptions of their identity and role. Despite the courage exhibited by the women who have come out to demand justice for themselves, one cannot be indifferent to the problems and tribulations such women face as they fight for their rights. Often the legal hurdles and confines of national spaces leave many such women in the lurches which has demotivated others from seeking justice.

The globalization process has created very significant implications since it implies movements and migration of peoples across national boundaries, but, with very little attention to governance with respect to international laws and policies. Abandonment of holiday brides finds its expression in the idea of "global city" which lacks a clear-cut definition of geographical boundaries (Sassen, 1991). This fuzziness of geographical boundaries in a globalized world has left little legal recourse available for abandoned women to protect their rights (Lodhia, 2010). As Sassen (2005) highlights, the transnational spaces will result in new types of legal subjects, which will render the legal remedies within the borders of the nation-state meaningless. Globalization without legal reforms in some areas of law has created a vacuum in addressing the needs of the holiday brides who are caught between the law of "their" home land vs. the land where their spouse lives and/or works.

\section{Policy perspectives}

The discussion leads us into the question: What are some key areas of legal concern for the lives of holiday brides?

The holiday brides find themselves caught in no man's land as there are legal limitations for trial of the husbands since they live in foreign lands. The case laws in table 1 clearly indicate this challenge. There have been no wide-scale successful attempts at executing joint treaties between countries whose families are split by geographical boundaries and have domestic violence related issues which makes the lives of some of the family members complicated due to the transnational status. What complicates the situation is the existence of different marriage laws based on religion in India. Furthermore, registration of marriage in India is not compulsory and universally enforced all over India. In recent times however, states like Punjab have made the registration of marriage compulsory and advocates have been demanding such a provision for all marriage taking place within the country to allow for the proper restitution of the rights of the abandoned wives in India. However, so far, there has not been much success with respect to this in all states and even in Punjab the enforceability of law leaves much to be desired. The implication is that, men can be married to their first spouse in India and, subsequently, marry someone else in the foreign land due to the lack of legal 
registration of marriage. While the Indian government recognizes the religious wedding as legal, often most other countries do not have such a system and therefore, legally unless the marriage registration paperwork is not available there is a lack of clarity as to the status of marriage. In fact, studies have shown that not only in India, but Indians in foreign lands such as USA also perform religious marriages and then take advantage of their spouse's status without getting their marriage legally registered (Kapur \& Zajicek, 2017). The lack of access to finances or knowledge about this information also creates problems for the holiday brides to secure alimony and child support. In India the taking or giving of dowry is prevalent in marriage ceremonies which is a criminal offense under article $498 \mathrm{~A}$ but dowry transfers are not taken into account when divorces are granted in foreign lands with wives in absentia. Again, there are also many cases wherein divorce granted in foreign lands is rejected by Indian courts since the woman did not have a fair chance to represent her case. However, this also leaves the woman in limbo as her husband who lives and works in a foreign land by all legal accounts is free from marriage.

The women in India is still considered married and is trying to fight to legally divorce and get justice. The civil rights nature of divorce cases makes the enforceability of such laws highly problematic when dealing with cases where families are split across national boundaries.

\section{Conclusion}

An important critique of law and policy that emerges from a deeper analysis of the lives of holiday brides is that national boundaries set the situations and life experiences of the holiday brides into confined spaces which constrains justice for them. In fact, as Lodhia (2010; p.173) states "new forms of mobility of culture, people, and ideas reveal the increased permeability of national boundaries but not their dissolution." To bring justice to holiday brides, newer policy proposals have been initiated such as declaration of marital status on the passport of all Nonresident Indians, attempts to bring in a Uniform Civil Code (UCC) which would mean same personal laws across all communities in India, and encouraging NRIs to marry under the Special Marriage Act to do away with religious differences. However, a careful look at these initiatives reveals that these attempts are primarily restitutive measures. We need to focus on both restitutive as well preventive measures to address the problem and bring justice to the holiday brides.

Policies and laws that cut across national boundaries to address issues of holiday brides are required. Abandonment which is so far not considered violence against women, needs to be viewed as such, given the mental torture and cruelty that these women undergo (Lodhia, 2010). Primarily, aspects of civil law fail to make it easy to adjudicate such cases and to enforce judgements. Therefore, what is rightly required is a holistic and systematic approach to address these issues by first rightly identifying all issues related to the problem. A dialogue is required between the affected nations to collaboratively find avenues to address the grievances of the affected spouses. In a global world, isolation in relation to law and policy is detrimental to addressing the root cause of the problem especially wherein new subjects are being created who fall in what we may call 'no-man's land" and therefore for whom real justice can only be brought about by working in conjunction rather than in isolation.

\section{References}

Abraham, M. (2008). Domestic violence and the Indian diaspora in the United States. In R. Palriwala and P. Uberoi (Eds.), Marriage, Migration and Gender (pp.303-325). Delhi: Sage Publications.

Anitha, S., Roy, A., \& Yalamarty, H. (2016). Disposable women: Abuse, violence and abandonment in transnational marriages. Lincoln: University of Lincoln.

Bhattacharjee, S. S. (2013). Distant silences and default judgements: Access to justice for transnationally abandoned women. University of Pennsylvania Journal of Law and Social Change, 16(1). 1-16.

Biao, X. (2008). Gender, Dowry and the migration system of Indian information technology professionals. In R. Palriwala and P. Uberoi (Eds.), Marriage, Migration and Gender (pp. 235-260). Delhi: Sage Publications.

Bradley, T., Tomalin, E., \& Subramaniam, M. (eds.) (2009) Dowry: Bridging the gap between theory and practice. London: Zed Books.

Dhawan, N. (2005). Women's role expectations and identity development in India. Psychology and 
Developing Societies, 17(1). 81-92.

Fulford, S. L. (2015). Marriage migration in India: Vast, varied, and misunderstood. Paper presented at International Conference on Migration and Development at AI Akhawayn University in Morocco.

Grewal, I \& Kaplan, C. (2002). Transnational practices and interdisciplinary feminist scholarship: Refiguring women's and gender studies. In R. Wiegman (Ed.) Womens' Studies on Its Own: A Next Wave Reader in Institutional Change (pp.). Durham: Duke University Press.

Jehan, K. (2011). Gender, globalization and the growth of dowry in South India (Doctoral Dissertation). Leeds: University of Leeds.

John, T. E. (2010). A study of fraudulent migratory marriages in Canada and India. Thesis submitted to Faculty of Law, University of Toronto.

Kalita, S. M. (2005). Immigrant wives' visa status keeps them out of workplace. Washington Post. October 3.

Kapur, S. \& Zajicek, A. (2017). Constructions of battered Asian Indian marriage migrants: The narratives of domestic violence advocates. Violence Against Women, 24(16), 1928-1948.

Kumari, R. (2010). Globalizing India and domestic violence against women. Dialogues, 11(3). n.a.

Liddle, J., \& Joshi R. (1986). Daughters of independence: gender, caste and class in India. United Kingdom. London: Zed Books Ltd., Rutgers University Press.

Lodhia, S. (2010). Constructing an imperfect citizen-subject: Globalization, national "security," and violence against South Asian women. Women's Studies Quarterly, 38(1/2). 161-177.

Nigam, S. (2019). Legislating on transnational dowry abuse: A ray of hope from Australia. Counter currents.org.

Patel, P., Handa, R., Anitha, S., \& Jahangir, S. (n.a.). Emerging issues for international family law: Part 3: Transnational marriage abandonment and the dowry question. FJL.

Prasad, M. M. (1998). Ideology of the Hindi film: A historical construction. New Delhi: Oxford University Press.

Sassen, S. (1991). Global City. Princeton University Press: New Jersey.

Sassen, S. (2005). The repositioning of citizenship and alienage: Emergent subjects and spaces for politics. Globalizations, 2(1), 79-94.

Stewart, A. (2013). Abuse, danger, and security in transnational marriages: Polity and community in India and the United Kingdom. Violence Against Women, 19(10), 1263-1281.

Venkatesan, V. (2018). Women abandoned by NRI husbands petition court for protection. Frontline, Published on November 21, 2018.

Waheed, A. (2009). Dowry among Indian Muslims. Indian Journal of Gender Studies, 16(1), 47-75. 